\title{
ANALISIS ALTERNATIF PERBAIKAN TANAH LUNAK DAN SANGAT LUNAK PADA JALAN TOL
}

\author{
Christian Eka Putra ${ }^{1}$ dan Chaidir Anwar Makarim² \\ ${ }^{1}$ Program Studi Sarjana Teknik Sipil, Universitas Tarumanagara, Jl. Letjen S. Parman No.1 Jakarta \\ christian.325160136@stu.untar.ac.id \\ ${ }^{2}$ Program Studi Sarjana Teknik Sipil, Universitas Tarumanagara, Jl. Letjen S. Parman No.1 Jakarta \\ chaidir259@gmail.com
}

Masuk: 13-07-2020, revisi: 25-07-2020, diterima untuk diterbitkan: 04-08-2020

\begin{abstract}
The existence of soft soil is one of the problems in the field of construction. Soft soil is soil that has high water content and low carrying capacity. In the case of this toll road, soil investigation at the site shows that the subgrade in the toll road planning is soft clay soil to a depth of 32 meters so that soil improvement is needed. High landfill built on soft subgrade without reinforcement will experience landslides. So it is necessary to strengthen the landfill and repair the subgrade to prevent road slides. The soil improvement methods in use are vacuum preloading and Prefabricated Vertical Drain with the vacuum functioning as an additional load. In addition to accelerating the consolidation process, the vacuum can also reduce the height of the embankment needed to achieve the desired planned road elevation. Strengthening with geotextile is also carried out on the landfill with a height of 5.94 meters so that there is no landslide on the fill. Using soil improvement methods such as vacuum preloading and prefabricated vertical drain will increase the bearing capacity of the soil so that differences in bearing capacity occur before and after repair.
\end{abstract}

Keywords: soft soil; settlement; PVD; vacuum preloading

\begin{abstract}
ABSTRAK
Keberadaan tanah lunak menjadi salah satu masalah dalam bidang konstruksi. Tanah lunak adalah tanah yang memiliki kadar air yang tinggi dan daya dukung yang rendah. Pada kasus jalan tol ini, penyelidikan tanah di lokasi menunjukan bahwa tanah dasar pada perencanaan jalan tol merupakan tanah lempung lunak hingga kedalaman 32 meter sehingga dibutuhkan perbaikan tanah dasar. Timbunan tinggi yang dibangun di atas tanah dasar lunak tanpa perkuatan akan mengalami kelongsoran. Sehingga diperlukan perkuatan timbunan dan perbaikan tanah dasar untuk mencegah kelongsoran jalan. Metode perbaikan tanah yang digunakan adalah vacuum preloading dan Prefabricated Vertical Drain dengan vacuum berfungsi sebagai beban tambahan. Selain mempercepat proses penurunan, vacuum juga dapat mengurangi tinggi timbunan yang dibutuhkan untuk mencapai elevasi jalan rencana yang diinginkan. Perkuatan dengan geotextile juga dilakukan pada timbunan dengan tinggi yang mencapai 5.94 meter supaya tidak terjadi kelongsoran pada timbunan tersebut. Dengan menggunakan metode perbaikan tanah berupa vacuum preloading dan prefabricated vertical drain akan meningkatkan daya dukung tanah sehingga akan diketahui perbedaan daya dukung yang terjadi sebelum dan sesudah diperbaiki.
\end{abstract}

Kata kunci: tanah lunak; penurunan; PVD; vacuum preloading

\section{PENDAHULUAN}

Jalan tol adalah jalan umum yang merupakan bagian sistem jaringan jalan dan akan mempermudah pengguna jalan untuk mempersingkat jarak dan waktu tempuh dari satu tempat ke tempat lain. Ditemukan pada jalan tol ini bahwa kedalaman tanah lunak bervariasi hingga $32 \mathrm{~m}$. Keberadaan Tanah lunak ini memberikan banyak kerugian seperti kurangnya daya dukung yang bisa menyebabkan mahalnya desain perencanaan, angka keamanan yang kecil dan bisa berbahaya dan memberikan kerugian seperti jalan mengalami penurunan yang menyebabkan jalan retak. Dikarenakan kedalaman tanah lunak yang cukup dalam, maka dibutuhkan perbaikan tanah untuk meningkatkan elevasi tanah dan juga menaikan daya dukung tanah dasar tersebut. Vertical Drain dan Preloading merupakan beberapa metode yang dapat digunakan sebagai perbaikan tanah. Metode Vacuum Preloading (Kjellman, 1952). Dimana Vacuum Preloading menghisap air dan udara pada tanah dasar sehingga mempercepat proses konsolidasi yang terjadi. 
Tujuan dilakukannya penelitian ini adalah untuk mengetahui pola pemasangan, jarak antar PVD yang baik dan dapat digunakan untuk mempercepat proses konsolidasi yang terjadi. Selain itu untuk mengetahui desain vacuum preloading dan timbunan yang dikombinasikan dengan timbunan dapat memberikan hasil yang sesuai dengan yang diinginkan. Manfaat dari penelitian ini adalah memberikan atlternatif desain perbaikan tanah dengan menggunakan PVD dan vacuum preloading yang dapat digunakan untuk mempercepat proses konsolidasi dan meningkatkan daya dukung tanah dasar.

\section{Tanah lunak}

Tanah adalah lapisan permukaan bumi yang berasal dari material induk yang telah mengalami proses lanjut, karena perubahan alami dibawah pengaruh air, udara, dan macam - macam organisme baik yang masih hidup maupun yang telah mati. Tingkat perubahan terlihat pada komposisi, struktur dan warna hasil pelapukan (Dokuchaev, 1870). Tanah lunak memiliki daya dukung tanah yang kecil, pemampatan yang besar dan waktu konsolidasi yang lama (Das, 1998). Tanah lunak dalam konstruksi menjadi permasalahan. Daya dukung yang rendan menyebabkan kerugian, mulai dari kerugian dari sisi biaya konstruksi yang semakin mahal hingga rendahnya angka keamanan sehingga menyebabkan terancamnya keselamatan konstruksi. Struktur yang dibuat tidak mampu berdiri secara stabil bahkan bisa roboh.

\section{Vacuum preloading}

Sama seperti PVD, vacuum preloading bertujuan untuk mempercepat proses konsolidasi yang terjadi. Vakum pada intinya adalah pengaplikasian beban sebesar $80 \mathrm{Kpa}$, sekitar $8 \mathrm{ton} / \mathrm{m}^{2}$ diatas tanah dasar sehingga air pori dan udara didalam tanahmenjadi berkurang dan proses konsolidasi dapat dipercepat. Metode vakum ini dapat mengurangi tinggi timbunan yang dibutuhkan sebagai beban untuk preloading.
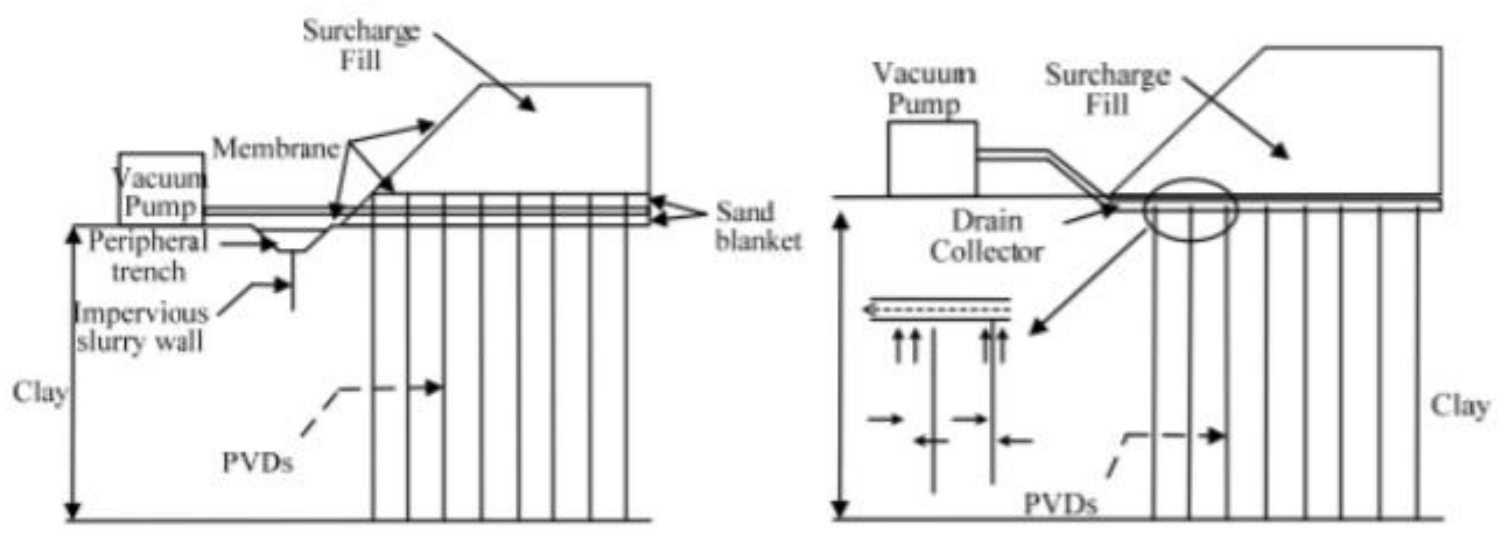

Gambar 1. Diagram metode vakum (Sumber: Indraratna, 2009)

Gambar 1 merupakan gambaran desain yang akan direncanakan, dimana air pada tanah akan keluar melewati PVD dengan preloading (surcharge fill) sebagai beban. Vacuum pump juga berfungsi sebagai beban pada proses keluarnya air dari tanah.

\section{Vertical drain}

Apabila waktu yang dibutuhkan untuk mencapai proses konsolidasi cukup lama, maka dibutuhkan vertical drain untuk membantu supaya waktu konsolidasi yang dibutuhkan dapat dipercepat. Vertical Drain berfungsi untuk memperpendek jalur air untuk keluar. Ada 2 pola yang dapat digunakan yaitu pola segitiga dan pola segiempat seperti Gambar 2 dan Gambar 3. 

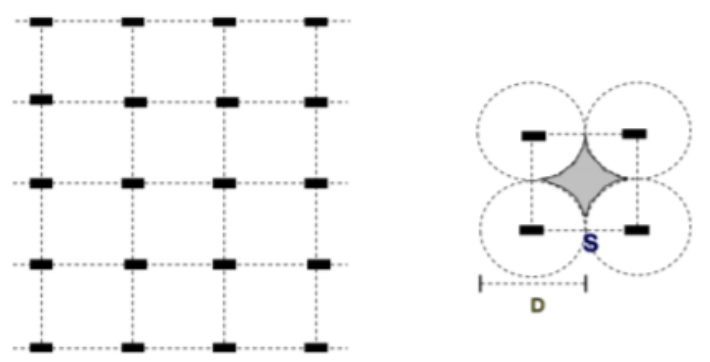

Gambar 2. Pola susunan PVD bujur sangkar (Sumber: Mochtar, 2000)
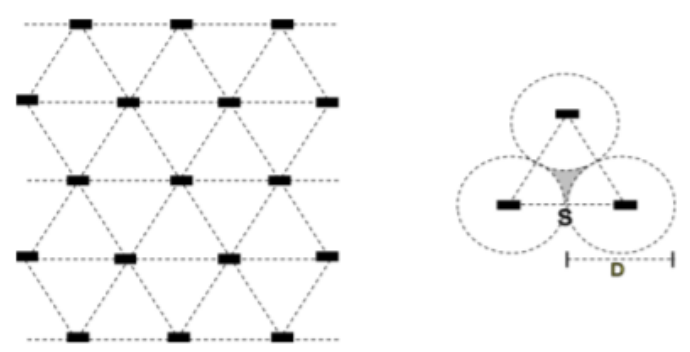

Gambar 3. Pola susunan PVD segitiga (Sumber: Mochtar, 2000)

Dalam mendesain PVD, faktor jarak dan koefisien konsolidasi menggunakan nilai arah horizontal. Salah satu cara yang dapat digunakan adalah metode Baron sebagai berikut :

$$
t=\frac{D^{2}}{8 c_{h}} 2 \cdot F_{n} \ln \frac{1}{1-U_{h}}
$$

dengan $\mathrm{t}=$ waktu konsolidasi, $\mathrm{D}=$ zona pengaruh $\mathrm{PVD}, \mathrm{Ch}=$ koefisien konsolidasi untuk aliran horizontal, Fn $=$ Faktor jarak drain, $\mathrm{d}=$ Diameter ekivalen dari PVD.

Untuk pola bujur sangkar nilai sebagai berikut :

$$
D=1,13 \times S
$$

Untuk pola segitiga :

$$
D=1,05 \times S
$$

dengan $\mathrm{s}=$ spacing atau jarak antar PVD.

\section{Penurunan tanah}

Jika lapisan tanah diberikan beban, maka tanah akan mengalami penurunan. Penurunan yang disebabkan oleh pengurangan rongga pori dan air di dalam tanah tersebut. Tanah didefinisikan secara umum adalah kumpulan dari bagian-bagian yang padat dan tidak terikat antara satu dengan yang lain (diantaranya mungkin material organik) rongga-rongga diantara material tersebut berisi udara dan air (Verhoef, 1994). Keluarnya air dan berkurangnya volume dari tanah tersebut menyebabkan naiknya daya dukung tanah dasar. Pada kasus tanah lempung yang berpemeabilitas rendah, tegangan air pori berlebih membutuhkan waktu yang cukup lama untuk teredisipasi. Ada dua jenis penurunan konsolidasi yaitu konsolidasi normal (normally consolidated) dan konsolidasi berlebih (over consolidated) Berdasarkan teori Terzaghi tentang konsolidasi satu dimensi, untuk tanah terkonsolidasi normal dapat dihitung dengan persamaan berikut :

$$
S_{c}=\frac{C_{c}}{1+e_{0}} H \log \left(\frac{\mathrm{Po}^{\prime}+\Delta \mathrm{p}}{\mathrm{Po}^{\prime}}\right)
$$

dengan $\mathrm{Sc}=$ penurunan konsolidasi, $\mathrm{Cc}=$ nilai compression index, $\mathrm{e}_{0}=$ Void Ratio awal, $\mathrm{H}=$ Tinggi awal terkonsolidasi, $\mathrm{Po}^{\prime}=$ Tegangan overburden efektif, $\mathrm{Po}^{\prime}+\Delta \mathrm{p}=$ Tegangan tanah akhir, yaitu tegangan tanah awal + tegangan akibat beban luar. 
Sedangkan untuk tanah yang terkonsolidasi berlebih, penurunan dapat dihitung dengan persamaan berikut untuk $\left(\mathrm{Po}^{\prime}+\Delta \mathrm{p}>\mathrm{Pc}\right):$

$$
S_{c}=\frac{C_{c}}{1+e_{0}} H \log \left(\frac{\mathrm{Pc}^{\prime}}{\mathrm{Po}^{\prime}}\right)+\frac{C_{c}}{1+e_{0}} H \log \left(\frac{\mathrm{Po}^{\prime}+\Delta \mathrm{p}}{\mathrm{Pc}^{\prime}}\right)
$$

Apabila $\left(\mathrm{Po}^{\prime}+\Delta \mathrm{p}<\mathrm{Pc}\right)$ :

$$
S_{c}=\frac{C_{S}}{1+e_{0}} H \log \left(\frac{\mathrm{Po}^{\prime}+\Delta \mathrm{p}}{\mathrm{Po}^{\prime}}\right)
$$

dengan Pc' = Tegangan Prakonsolidasi.

\section{Lapisan tanah compressible}

Untuk tebal lapisan tanah compressible yang diperhitungkan adalah tanah yang bisa mengalami pemampatan proses konsolidasi primer, yaitu yang memiliki nilai N-SPT $>10$ dianggap sudah tidak dapat mengalami konsolidasi. seperti yang tertulis pada Tabel 1.

Tabel 1. Hubungan N-SPT terhadap konsistensi tanah lempung (Terzaghi dan Peck, 1967)

\begin{tabular}{cccc}
\hline Consistency & $\begin{array}{c}\text { Unconfined Compression } \\
\text { Strength, } q_{u}\left(\mathrm{kN} / \mathrm{m}^{2}\right)\end{array}$ & $\begin{array}{c}\text { N-SPT } \\
(\text { blows per ft })\end{array}$ & $\begin{array}{c}\text { Saturated Unit } \\
\text { Weight, } \\
\left(\mathrm{kN} / \mathrm{m}^{3}\right)\end{array}$ \\
\hline Very Soft & $0-25$ & $0-2$ & $<16$ \\
Soft & $25-50$ & $2-4$ & $16-19$ \\
Medium & $50-100$ & $4-8$ & $17-20$ \\
Stiff & $100-200$ & $8-15$ & $18-20$ \\
Very Stiff & $200-400$ & $15-30$ & $19-22$ \\
Hard & $>400$ & $>30$ & $>20$ \\
\hline
\end{tabular}

\section{Distribusi tegangan tanah}

Distribusi tegangan tanah adalah pembagian beban yang diterima oleh tanah. Berdasarkan grafik Osterberg besarnya nilai koefisien pengaruh I untuk perhitungan besarnya tegangan vertikal yang terjadi dapat dilihat pada grafik berikut :

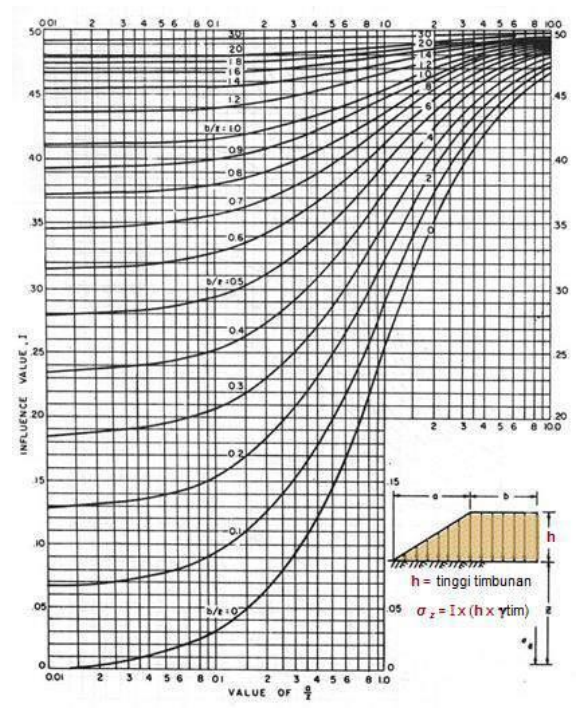

Gambar 4. Grafik faktor pengaruh beban bentuk trapesium (Mochtar)

$$
\Delta P=I \times q_{o}
$$


dengan $\mathrm{I}=$ faktor pengaruh, qo = beban terbagi rata di atas.

\section{Waktu penurunan konsolidasi}

Hal yang mempengaruhi waktu penurunan adalah panjang lintasan air untuk terdisipasi. Pada tanah yang terkonsolidasi tidak dengan menggunakan PVD, pengaliran yang terjadi hanya arah vertikal. Menurut Terzaghi dalam (B. M. Das), lama waktu konsolidasi dapat dicari dengan persamaan berikut:

$$
t=\frac{T_{v}\left(H_{d r}\right)^{2}}{C_{v}}
$$

dengan $\mathrm{t}=$ waktu konsolidasi, $\mathrm{Tv}=$ faktor waktu, $\mathrm{Hdr}=$ panjang aliran air, $\mathrm{Cv}=$ koefisien konsolidasi vertikal . Untuk derajat konsolidasi antara 0-60\% dirumuskan dengan :

$$
U=\left(2 \sqrt{\frac{T_{v}}{\pi}}\right) 100 \%
$$

dengan $\mathrm{U}=$ derajat konsolidasi, $\mathrm{TV}=$ faktor waktu.

\section{METODE PENELITIAN}

Dalam penelitian ini dilakukan beberapa tahapan sebagai berikut :

1. Tahapan pertama, melakukan pengumpulan data data parameter tanah, data beban di atas tanah, beban timbunan, beban jalan tol, data PVD dan juga geometri timbunan.

2. Tahapan kedua, pengumpulan informasi yang berkaitan dengan perhitungan desain PVD dan vacuum preloading, penurunan tanah, waktu konsolidasi dari jurnal dan buku yang tersedia.

3. Tahapan ketiga, melakukan korelasi data pada parameter tanah dan pendekatan dari data-data yang ada dan dibutuhkan untuk perhitungan penurunan tanah, waktu konsolidasi dan stabilitas timbunan.

4. Tahapan keempat, melakukan analisis untuk penurunan yang terjadi, waktu penurunan dan derajat konsolidasi, serta stabilitas timbunan dan desain geotextile sebagai perkuatan timbunan yang digunakan.

5. Tahapan kelima, penjabaran hasil perencanaan tingg timbunan preloading sesuai dengan hasil yang diinginkan, desain PVD, juga stabilitas timbunan yang dihasilkan. Setelah itu didapatkan hasil kesimpulan apakah metode vacuum preloading dan PVD yang direncanakan sesuai dengan yang diinginkan atau tidak.

\section{HASIL DAN PEMBAHASAN}

Pada perencanaan ini digunakan 3 titik bor yang berbeda serta dilakukan pengambilan sampel pada ketiga titik tersebut. Analisis dilakukan dengan geometri timbunan pada BH-1. Setelah dilakukan korelasi parameter pada data tanah, akan dilanjutkan dengan perhitungan tinggi timbunan actual (Hinitial) dengan Hfinal yang sudah direncanakan. Data korelasi timbunan dari BH-1, BH-2 dan BH-3 adalah sebagai berikut :

Tabel 2. Data parameter tanah

\begin{tabular}{lccccccccc}
\hline Soil & $\begin{array}{c}\text { Elevation } \\
(\mathrm{m})\end{array}$ & $\begin{array}{c}\text { Ysat } \\
\left(\mathrm{kN} / \mathrm{m}^{3}\right)\end{array}$ & $\mathrm{e}$ & $\begin{array}{c}\mathrm{Po}^{\prime} \\
\left(\mathrm{kN} / \mathrm{m}^{2}\right)\end{array}$ & $\mathrm{Cc}$ & $\begin{array}{c}\mathrm{Cu} \\
\left(\mathrm{kN} / \mathrm{M}^{2}\right)\end{array}$ & OCR & $\begin{array}{c}\mathrm{Pc} \\
\left(\mathrm{kN} / \mathrm{m}^{2}\right)\end{array}$ \\
\hline CLAY & 0 & 1,8 & 17,212 & 0,45 & 15,49 & 0,115 & 30 & & \\
CLAY & 1,8 & 4 & 17,212 & 0,55 & 37,92 & 0,23 & 32,688 & 10,685 & 405,134 \\
CLAY & 4 & 6 & 16,615 & 1,103 & 52,46 & 0,866 & 39,226 & 3,5969 & 188,709 \\
CLAY & 6 & 8 & 15,928 & 0,55 & 65,01 & 0,23 & 26,151 & 4,1828 & 271,917 \\
SILT & 8 & 10 & 15,481 & 1,1 & 76,42 & 0,47 & 13,075 & 1,9624 & 149,969 \\
SILT & 10 & 14 & 15,978 & 1,1 & 93.86 & 0,47 & 13,075 & 2,1306 & 199,980 \\
SILT & 14 & 16 & 15,196 & 1,5 & 111 & 0,686 & 6,37 & 1,9809 & 219,899 \\
SILT & 16 & 18 & 17,299 & 1,5 & 123,5 & 0,686 & 13,075 & 0,8693 & 107,370 \\
SILT & 18 & 20 & 17,318 & 1,5 & 138,1 & 0,686 & 6,537 & 0,3886 & 53,685 \\
SILT & 20 & 22 & 17,318 & 1,5 & 152,8 & 0,686 & 19,613 & 1,0544 & 161,080 \\
SILT & 22 & 28 & 17,318 & 1,5 & 182 & 0,686 & 26,151 & 2,1506 & 391,503 \\
SILT & 28 & 30 & 17,358 & 1,5 & 211,4 & 0,686 & 26,151 & 1,0167 & 214,892 \\
SILT & 30 & 32 & 17,279 & 1,5 & 226 & 0,686 & 71,915 & 2,6151 & 590,985 \\
\hline
\end{tabular}


Untuk menentukan tinggi timbunan yang diperlukan, pertama dihitung terlebih dahulu menghitung tinggi timbunan 1,2,3,4,5 dan 6 meter. Beban total akibat tinggi timbunan dan beban jalan adalah berikut :

Tabel 3. Beban total akibat tinggi timbunan dengan beban jalan

\begin{tabular}{ccccccc}
\hline $\begin{array}{c}\text { H beban } \\
\text { timbunan }(\mathrm{m})\end{array}$ & $\begin{array}{c}\text { Q lalu } \\
\text { lintas } \\
\left(\text { ton } / \mathrm{m}^{2}\right)\end{array}$ & $\begin{array}{c}\text { H traffic } \\
(\mathrm{m})\end{array}$ & H total $(\mathrm{m})$ & $\mathrm{a}(\mathrm{m})$ & $\mathrm{b}(\mathrm{m})$ & $\begin{array}{c}\text { q total } \\
\left(\text { ton } / \mathrm{m}^{2}\right)\end{array}$ \\
\hline 1 & 1,5054 & 0,9408 & 1,9408 & 3,8817 & 12,55 & 3,105 \\
2 & 1,5054 & 0,9408 & 2,9408 & 5,8817 & 12,55 & 4,705 \\
3 & 1,5054 & 0,9408 & 3,9408 & 7,8817 & 12,55 & 6,305 \\
4 & 1,5054 & 0,9408 & 4,9408 & 9,8817 & 12,55 & 7,905 \\
5 & 1,5054 & 0,9408 & 5,9408 & 11,8817 & 12,55 & 9,505 \\
6 & 1,5054 & 0,9408 & 6,9408 & 13,8817 & 12,55 & 11,105 \\
\hline
\end{tabular}

Untuk menghitung penurunan sebelumnya perlu menghitung perubahan tegangan seperti contoh :

$\frac{A}{Z}=1,3385$

$\frac{B}{Z}=4,328$, dari grafik didapatkan nilai $\mathrm{I}=0,5$.

Karena beban akibat timbunan berbentuk trapezium maka :

$\Delta p=2 \times q \times I=3,105417$

Po' $+\Delta \mathrm{p}=6,970402^{\text {ton }} / \mathrm{m}^{2}$

Po’ $+\Delta \mathrm{p}<$ Pc, maka :

$S_{c}=\frac{C_{S}}{1+e_{0}} H \log \left(\frac{\mathrm{Po}^{\prime}+\Delta \mathrm{p}}{\mathrm{Po}^{\prime}}\right)=0,01115 \mathrm{~m}$.

Hasil penurunan tiap lapisan dijumlahkan. Untuk perhitungan beban akibat perkerasan, menggunakan cara sama namun menggunakan grafik berbentuk persegi. Didapatkan hasil Sc, Hinitial, Hfinal akhir sebagai berikut :

Tabel 4. Hasil Hinitial, Hfinal, Sctotal

\begin{tabular}{ccccccccc}
\hline $\begin{array}{c}\text { Htimb. } \\
(\mathrm{m})\end{array}$ & $\begin{array}{c}\mathrm{q} \\
\left(\text { ton } / \mathrm{m}^{2}\right)\end{array}$ & $\begin{array}{c}\text { Hinitial } \\
(\mathrm{m})\end{array}$ & $\begin{array}{c}\text { Sc } \\
\text { Timbunan } \\
(\mathrm{m})\end{array}$ & $\begin{array}{c}\text { Tebal } \\
\text { Pavement } \\
(\mathrm{m})\end{array}$ & $\begin{array}{c}\text { Sc beban } \\
\text { Pavement } \\
(\mathrm{m})\end{array}$ & $\begin{array}{c}\text { Sc } \\
\text { Vacuum } \\
(\mathrm{m})\end{array}$ & $\begin{array}{c}\mathrm{H} \\
\text { final } \\
(\mathrm{m})\end{array}$ & $\begin{array}{c}\text { Sc Total } \\
(\mathrm{m})\end{array}$ \\
\hline 1 & 3,105 & 2,081 & 0,225 & 0,76 & 0,0993 & 0,6910 & 0,8851 & 1,0157 \\
2 & 4,707 & 3,157 & 0,346 & 0,76 & 0,0966 & 0,6910 & 1,8423 & 1,1342 \\
3 & 6,305 & 4,226 & 0,456 & 0,76 & 0,0931 & 0,6910 & 2,8045 & 1,2408 \\
4 & 7,905 & 5,289 & 0,557 & 0,76 & 0,0901 & 0,6910 & 3,7699 & 1,3382 \\
5 & 9,505 & 6,364 & 0,677 & 0,76 & 0,0880 & 0,6910 & 4,7267 & 1,4570 \\
6 & 11,105 & 7,434 & 0,789 & 0,76 & 0,0864 & 0,6910 & 5,6865 & 1,5667 \\
\hline
\end{tabular}

Setelah didapatkan hasil berikut, dapat dibuat grafik hubungan antara Hinitial dengan Hfinal dimana Hfinal adalah elevasi tinggi jalan yang direncanakan. Pada perencanaan ini akan ditinjau STA 109+000, STA 109+025. STA 109+050, STA 109+075, STA 109+100, STA 109+125, STA 109+150. Berikut grafik hubungan antara Hinitial dan Hfinal, dan Hfinal dan settlement : 


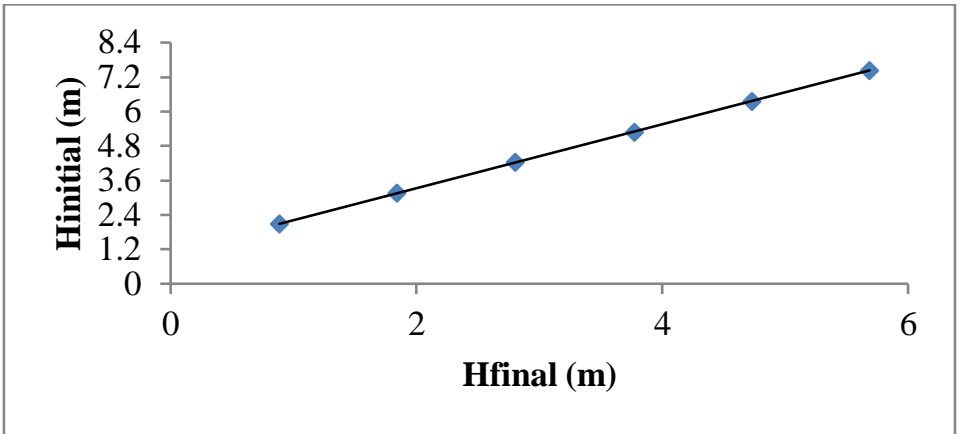

Gambar 5. Grafik hubungan antara Hinitial dengan Hfinal

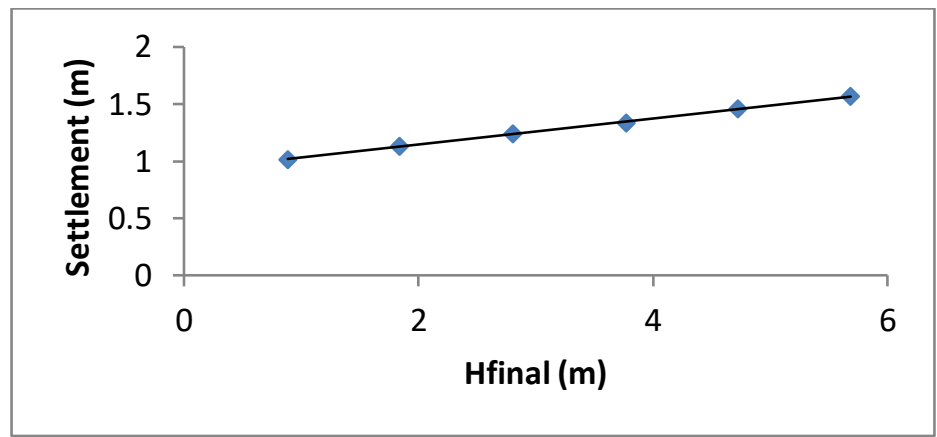

Gambar 6. Grafik hubungan antara Hfinal dan Sc

Dari kedua gambar diatas bisa diambil persamaan untuk mendapatkan nilai Hinitial dan Sc. Dari persamaan tersebut dapat ditentukan berapa Hinitial dan penurunan (Sc) yang dihasilkan sesuai dengan Hfinal yang direncanakan. Hasil akhir yang didapat sebagai berikut :

Tabel 5. Hasil Hinitial, Hfinal, dan Sc

\begin{tabular}{ccccc}
\hline STA & Existing Ground $(\mathrm{m})$ & $\mathrm{H}$ final $(\mathrm{m})$ & H initial $(\mathrm{m})$ & $\begin{array}{c}\text { Settlement } \\
(\mathrm{m})\end{array}$ \\
\hline $109+000$ & 2,867 & 7,222 & 5,949 & 1,413 \\
$109+025$ & 2,916 & 6,964 & 5,607 & 1,378 \\
$109+050$ & 2,965 & 6,754 & 5,319 & 1,349 \\
$109+075$ & 3,04 & 6,594 & 5,057 & 1,322 \\
$109+100$ & 3,07 & 6,484 & 4,901 & 1,306 \\
$109+125$ & 3,06 & 6,408 & 4,828 & 1,299 \\
$109+150$ & 3,163 & 6,333 & 4,629 & 1,278 \\
\hline
\end{tabular}

Pada perhitungan ini dicoba variasi pemasangan PVD bujur sangkar dan segitiga dengan jarak pemasangan 0,8 hingga $2 \mathrm{~m}$. Jarak pemasangan dihitung tiap $0,2 \mathrm{~m}$. Berikut contoh perhitungan perencanaan PVD pola pemasangan segitiga :

$\mathrm{Cv}=0,0457 \mathrm{~m}^{2} /$ minggu

$\mathrm{t}=1$ minggu

$\mathrm{Hdr}=32 \mathrm{~m}$

$\mathrm{Tv}=\frac{1 \text { minggu } \times 0,04571 \mathrm{~m}^{2} / \text { minggu }}{32^{2}}$

Uv $\quad=\left(2 \sqrt{\frac{4,46386 \times 10^{-5}}{\pi}}\right) \times 100 \%=7,5389 \times 10^{-3}=0,753894 \%$

Setelah mnedapatkan nilai Uv kita perlu menghitung nilai Uh sebagai berikut : 


$$
\begin{array}{ll}
\mathrm{Cv}=0,0457 & \mathrm{~m}^{2} / \text { minggu } \\
\text { Lebar PVD } & =100 \mathrm{~mm} \\
\text { Tebal PVD (b) } & =4 \mathrm{~mm} \\
\mathrm{dw} & =\frac{2(a+b)}{\pi} \\
& =66,20845 \mathrm{~mm}
\end{array}
$$

D = Diameter ekivalen dari lingkaran tanah

$$
\begin{array}{ll}
\mathrm{n} & =\mathrm{D} / \mathrm{dw} \\
& =840 / 66,24203 \\
& =12,680769 \\
& =\ln (12,680769)-\frac{3}{4} \\
& =1,790086 \\
\mathrm{~F}(\mathrm{n}) \quad & 1-\left[\frac{1}{\left[\frac{1 \times 8 \times 0,09142}{0,84^{2} \times 2 \times 1,790086}\right]}\right]=0,2513722=25,127 \% \\
\mathrm{Uh} & \begin{array}{l}
\bar{u}=\left[1-\left(1-u_{h}\right) \times\left(1-U_{v}\right)\right] \times 100 \% \\
\bar{u}=\left[1-(1-0,2513722) \times\left(1-7,5389 \times 10^{-3}\right)\right] \times 100 \% \\
=25,7016 \%
\end{array}
\end{array}
$$$$
=1,05 \times \mathrm{S}
$$$$
=1,05 \times 0,8
$$$$
=0,84 \mathrm{~m}=840 \mathrm{~mm}
$$

Setelah perhitungan selesai, pola pemasangan segitiga dipilih karena menghasilkan waktu yang lebih cepat untuk tercapainya derajat konsolidasi 90\% dengan jarak pemasangan antar PVD adalah 1m. Waktu yang dihasilkan adalah 14 minggu.

Tabel 6. Hasil derajat konsolidasi pada pemasangan PVD pola segitiga

\begin{tabular}{ccccccc}
\hline $\begin{array}{c}\text { T } \\
\text { (minggu) }\end{array}$ & 0,8 & 1 & 1,2 & 1,5 & 1,7 & 2 \\
\hline 1 & 25,702 & 15,829 & 10,639 & 6,622 & 5,132 & 3,749 \\
2 & 44,554 & 28,839 & 19,792 & 12,420 & 9,603 & 6,947 \\
3 & 58,592 & 39,795 & 27,955 & 17,798 & 13,800 & 9,973 \\
4 & 69,065 & 49,044 & 35,263 & 22,817 & 17,771 & 12,869 \\
5 & 76,883 & 56,862 & 41,816 & 27,512 & 21,541 & 15,651 \\
6 & 82,722 & 63,475 & 47,697 & 31,910 & 25,125 & 18,330 \\
7 & 87,085 & 69,070 & 52,977 & 36,033 & 28,536 & 20,914 \\
8 & 90,345 & 73,805 & 57,720 & 39,899 & 31,784 & 23,408 \\
9 & 92,782 & 77,813 & 61,981 & 43,528 & 34,880 & 25,817 \\
10 & 94,603 & 81,207 & 65,811 & 46,934 & 37,830 & 28,146 \\
\hline
\end{tabular}


Lanjutan Tabel 6. Hasil derajat konsolidasi pada pemasangan PVD pola segitiga

\begin{tabular}{ccccccc}
\hline $\begin{array}{c}\text { T } \\
\text { (minggu })\end{array}$ & 0,8 & 1 & 1,2 & 1,5 & 1,7 & 2 \\
\hline 11 & 95,964 & 84,080 & 69,252 & 50,131 & 40,644 & 30,397 \\
12 & 96,982 & 86,514 & 72,346 & 53,133 & 43,327 & 32,574 \\
13 & 97,743 & 88,575 & 75,128 & 55,953 & 45,886 & 34,680 \\
14 & 98,312 & 90,321 & 77,629 & 58,601 & 48,328 & 36,718 \\
15 & 98,738 & 91,799 & 79,877 & 61,088 & 50,658 & 38,690 \\
16 & 99,056 & 93,052 & 81,899 & 63,425 & 52,881 & 40,599 \\
17 & 99,294 & 94,113 & 83,718 & 65,621 & 55,003 & 42,447 \\
18 & 99,472 & 95,012 & 85,353 & 67,684 & 57,028 & 44,235 \\
19 & 99,605 & 95,773 & 86,824 & 69,622 & 58,961 & 45,967 \\
20 & 99,705 & 96,419 & 88,146 & 71,443 & 60,806 & 47,644 \\
21 & 99,779 & 96,965 & 89,336 & 73,155 & 62,567 & 49,267 \\
22 & 99,835 & 97,428 & 90,406 & 74,764 & 64,249 & 50,840 \\
23 & 99,876 & 97,821 & 91,369 & 76,275 & 65,854 & 52,362 \\
24 & 99,908 & 98,153 & 92,235 & 77,696 & 67,387 & 53,837 \\
25 & 99,931 & 98,435 & 93,014 & 79,032 & 68,850 & 55,265 \\
\hline
\end{tabular}

Tabel 7. Perubahan nilai $\mathrm{Cu}$ akibat beban bertahap pada tinggi timbunan kritis

\begin{tabular}{|c|c|}
\hline$\sigma^{\prime}\left(\operatorname{ton} / \mathrm{m}^{2}\right)$ & $\mathrm{Cu}\left(\mathrm{kN} / \mathrm{m}^{2}\right)$ \\
\hline 2,181 & 11,264 \\
\hline 4,502 & 15,560 \\
\hline 5,982 & 18,298 \\
\hline 7,227 & 20,584 \\
\hline 8,387 & 22,727 \\
\hline 10,116 & 25,922 \\
\hline 11,827 & 29,085 \\
\hline 13,069 & 31,379 \\
\hline 14,533 & 34,085 \\
\hline 15,999 & 36,795 \\
\hline 18,931 & 42,206 \\
\hline 21,880 & 47,654 \\
\hline 23,359 & 50,387 \\
\hline
\end{tabular}


Nilai $\mathrm{Cu}$ baru yang didapatkan dicoba pada program bantu dengan tinggi timbunan kritis yaitu 1,5 m sebagai berikut :

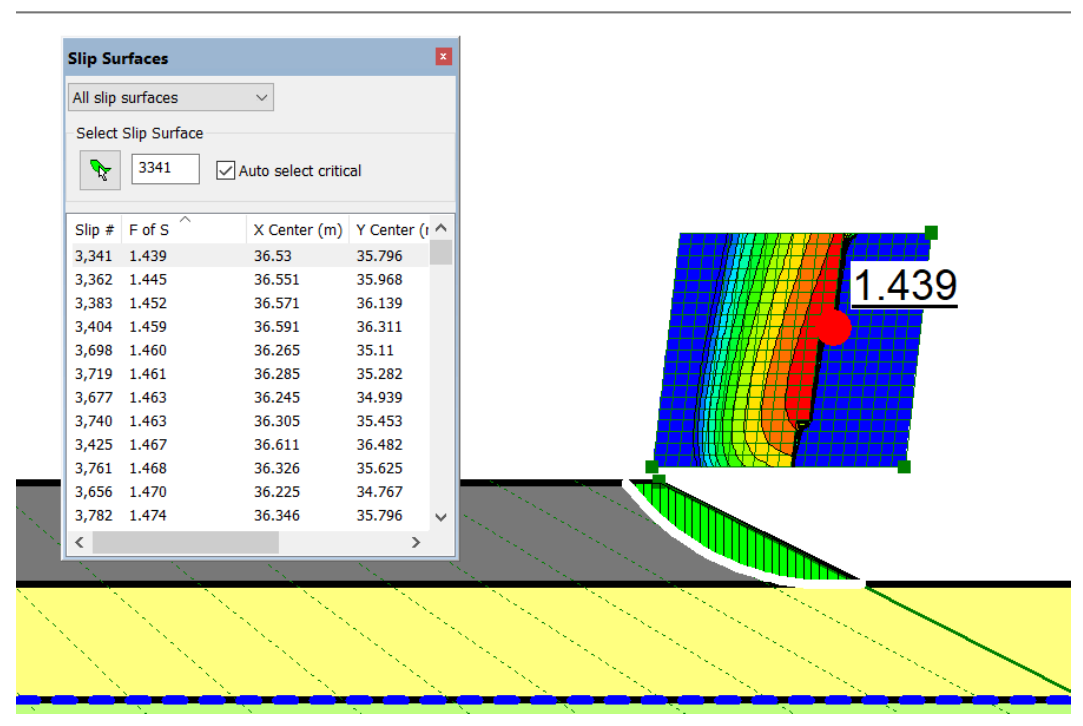

Gambar 7. Hasil analisis program pada timbunan $1,5 \mathrm{~m}$

Penurunan akibat timbunan bertahap dihitung seperti penurunan akibat timbunan dan beban perkerasan seperti berikut :

$$
\begin{array}{ll}
\text { Po } & =3,865^{t} / \mathrm{m}^{2} \\
\text { Pc' } & =41,298^{t} / \mathrm{m}^{2} \\
\mathrm{e}_{0} & =0,55 \\
\mathrm{Cc} & =0,23 \\
\mathrm{Cs} & =0,0153 \\
\Delta \mathrm{p} 1 & =0,8^{t} / \mathrm{m}^{2}
\end{array}
$$

Karena Po' $+\Delta \mathrm{p} 1<\mathrm{Pc}$ maka,

$$
\begin{aligned}
S_{c} & =\frac{C_{s}}{1+e_{0}} H \log \left(\frac{\mathrm{Po}^{\prime}+\Delta \mathrm{p}}{\mathrm{Po}^{\prime}}\right) \\
S_{c} & =\frac{0,0307}{1+0,55} \times 2.2 \times \log \left(\frac{3,865+0,8}{3,865}\right) \\
& =0,0035601 \mathrm{~m}
\end{aligned}
$$

Sc dijumlahkan pada tiap lapisnya lalu dihitung sesuai dengan derajat konsolidasi dan waktu sebagai berikut untuk minggu 1:

$$
\begin{array}{ll}
\mathrm{Sc}_{\text {kumulatif }} & =\mathrm{Sc} 1=0,0547 \mathrm{~m} \\
\mathrm{U}_{1} & =15,829 \%=0,15829 \\
\mathrm{Sc}_{\text {minggu 1 }} & =\mathrm{Sc}_{\text {kumulatif }} \times \mathrm{U} 1 \\
& =0,0547 \times 0,15829 \\
& =0,008658 \mathrm{~m}
\end{array}
$$

Setelah perhitungan pemampatan selesai, dapat dibuat grafik untuk mengetahui pemampatan yang terjadi setiap minggunya. Grafik pemampatan akibat timbunan bertahap adalah sebagai berikut. 


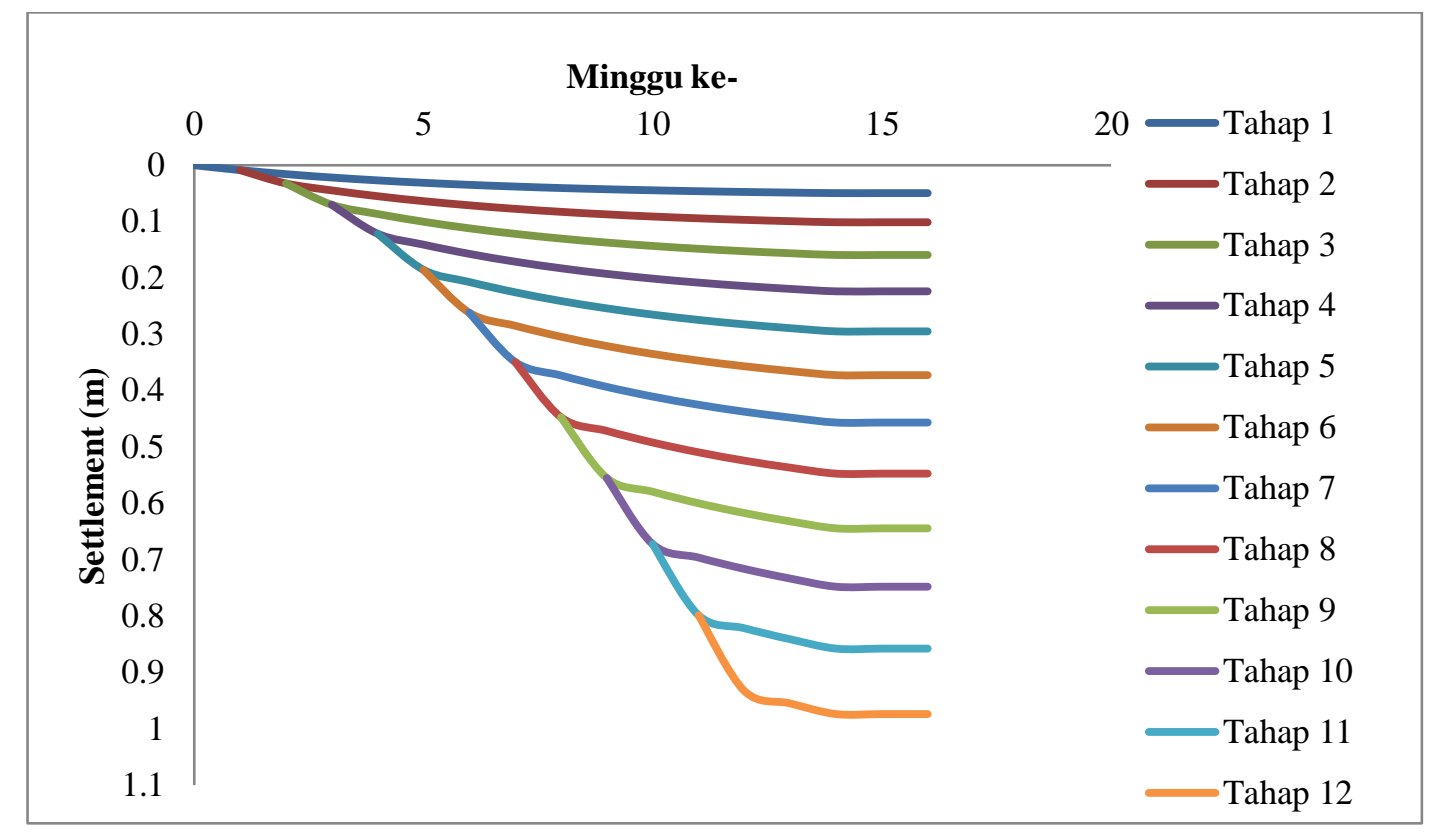

Gambar 8. Grafik settlement akibat beban bertahap

Untuk perhitungan stabilitas timbunan akan menggunakan program bantu dicoba pada tinggi timbunan 5,94 m dan didapatkan hasil sebagai berikut :

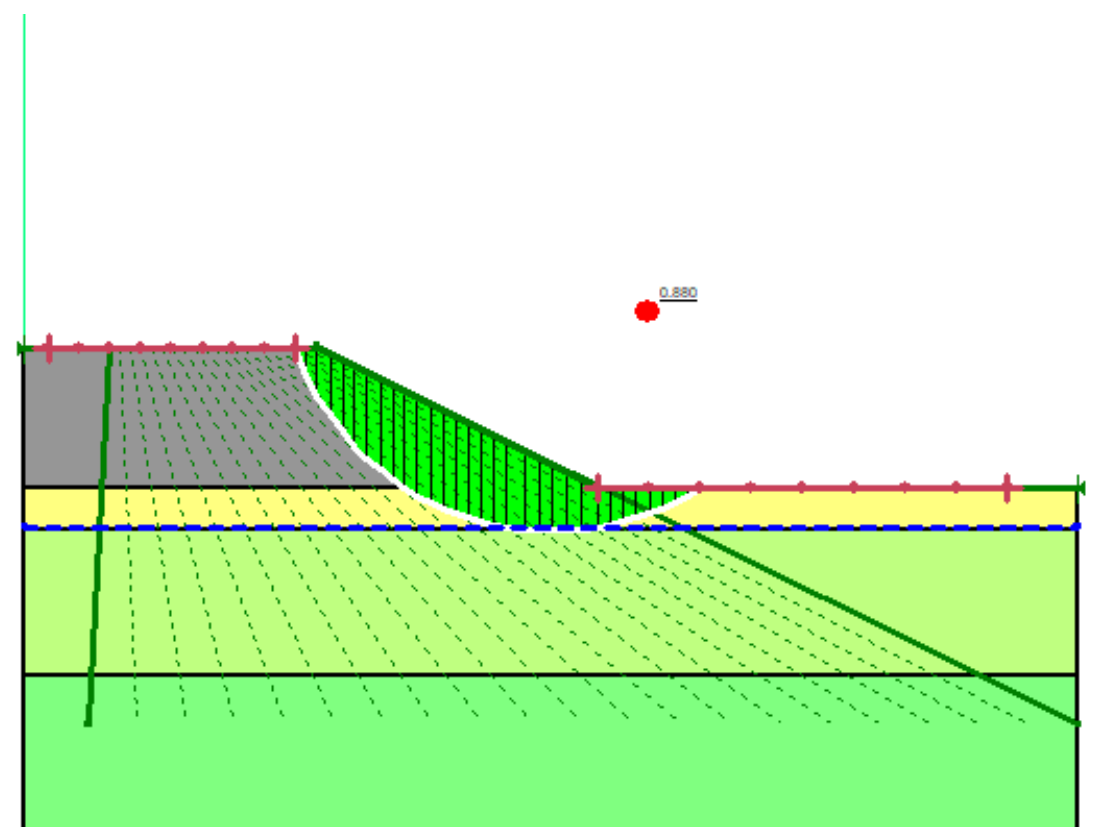

Gambar 9. Hasil analisa program bantu dengan tinggi timbunan $5.94 \mathrm{~m}$

Untuk perhitungan geotextile akan menggunakan tensile strength sebesar 200 dan $400 \mathrm{kN} / \mathrm{m}$ dan didapatkan hasil sebagai berikut :

$$
\begin{aligned}
& \text { Tallow }=\text { Tultimate } \times\left(\frac{1}{F S i d \times F S c r \times F S c d \times F S b d}\right) \\
& \mathrm{FS}_{\mathrm{id}}=1,5 \\
& \mathrm{FS}_{\mathrm{cr}}=3 \\
& \mathrm{FS}_{\mathrm{cd}}=1,2 \\
& \mathrm{FS}_{\mathrm{bd}}=1,15
\end{aligned}
$$


Tallow $=200 \times\left(\frac{1}{1,5 \times 3 \times 1,2 \times 1,15}\right)$

$\mathrm{SF}=0,88$

$\mathrm{R}=11,629$

$\mathrm{SF}$ rencana $=1,5$

$\mathrm{M}_{\mathrm{R}}=2391,3 \mathrm{kNm}$

$\mathrm{M}_{\mathrm{D}}=2717,386 \mathrm{kNm}$

$\Delta \mathrm{M}_{\mathrm{R}}=1684,779 \mathrm{kNm}$

Dari hasil perhitungan $\Delta \mathrm{MR} \leq$ Tallow $\mathrm{x} \sum \mathrm{Ri}$, didapat kebutuhan geotextile sebanyak 17 lapis dengan jumlah lapis masing-masing 1 lembar.

Panjang geotextile di belakang bidang longsor pada lapisan pertama adalah

$\mathrm{L}_{\mathrm{e}}=\frac{\text { Tallow } \times \text { SFrencana }}{2 \times \tau i \times E}$

$=0,63077 \mathrm{~m}$

Tabel 8. Perhitungan panjang geotextile

\begin{tabular}{ccccccccc}
\hline Lapisan & Jumlah & $\begin{array}{c}\sigma^{\prime} \\
\left(\mathrm{kN} / \mathrm{m}^{2}\right)\end{array}$ & $\begin{array}{c}\tau \text { timb } \\
\left(\mathrm{kN} / \mathrm{m}^{2}\right)\end{array}$ & $\begin{array}{c}\tau \text { tanah } \\
\text { dasar } \\
\left(\mathrm{kN} / \mathrm{m}^{2}\right)\end{array}$ & $\begin{array}{c}\text { Le } \\
(\mathrm{m})\end{array}$ & Ld (m) & $\begin{array}{c}\text { Ltotal } \\
(\mathrm{m})\end{array}$ & $\begin{array}{c}\text { Ltotal } \\
(\mathrm{m})\end{array}$ \\
\hline 1 & 1 & 94,14 & 54,35 & 41,38 & 0,63 & 8,25 & 8,88 & 17,76 \\
2 & 1 & 90,22 & 52,08 & 40,07 & 0,65 & 8,18 & 8,83 & 17,67 \\
3 & 1 & 86,3 & 49,82 & 38,76 & 0,68 & 8,01 & 8,72 & 17,39 \\
4 & 1 & 82,38 & 47,56 & 37,45 & 0,71 & 7,78 & 8,49 & 16,98 \\
5 & 1 & 78,45 & 45,29 & 36,15 & 0,74 & 7,61 & 8,36 & 16,72 \\
6 & 1 & 74,53 & 43,03 & 34,84 & 0,77 & 7,38 & 8,15 & 16,31 \\
7 & 1 & 70,61 & 40,76 & 33,53 & 0,81 & 7,16 & 7,98 & 15,96 \\
8 & 1 & 66,69 & 38,50 & 32,22 & 0,85 & 6,89 & 7,75 & 15,51 \\
9 & 1 & 62,76 & 36,23 & 30,92 & 0,89 & 6,65 & 7,55 & 15,10 \\
10 & 1 & 58,84 & 33,97 & 29,61 & 0,95 & 6,36 & 7,31 & 14,60 \\
11 & 1 & 54,92 & 31,70 & 28,30 & 1,00 & 6,05 & 7,06 & 14,13 \\
12 & 1 & 50,99 & 29,44 & 26,99 & 1,07 & 5,74 & 6,81 & 13,62 \\
13 & 1 & 47,07 & 27,17 & 25,69 & 1,14 & 5,38 & 6,53 & 13,06 \\
14 & 1 & 43,15 & 24,91 & 24,38 & 1,22 & 5,06 & 6,29 & 12,58 \\
15 & 1 & 39,23 & 22,64 & 23,07 & 1,32 & 4,72 & 6,04 & 12,07 \\
16 & 1 & 35,33 & 20,38 & 21,76 & 1,43 & 4,376 & 5,80 & 11,69 \\
17 & 1 & 31,38 & 18,11 & 20,46 & 1,56 & 4,04 & 5,61 & 11,21 \\
\hline
\end{tabular}

\section{KESIMPULAN DAN SARAN}

\section{Kesimpulan}

1. Besar settlement total pada jalan tol adalah $1,413528 \mathrm{~m}$ dimana penurunan tersebut diakibatkan oleh beban timbunan, beban perkerasan, beban lalu lintas dan juga vacuum. Penurunan sebesar 1,413528 $\mathrm{m}$ adalah penurunan terbesar yang terjadi pada STA 109+000, sedangkan pada STA yang lain mengalami penurunan bervariasi disebabkan oleh tinggi timbunan yang berbeda sesuai dengan elevasi rencana jalan tol.

2. Elevasi rencana jalan tol tertinggi adalah $+7,222 \mathrm{~m}$ pada STA $109+000$. Tinggi timbunan yang dibutuhkan pada perencanaan PVD penuh setinggi 5,949 m dengan tambahan existing ground pada lapangan maka tinggi akhir rencana dapat tercapai. 
3. Pemasangan PVD sepanjang tanah lunak menggunakan pola segitiga dengan jarak $1 \mathrm{~m}$, dimana untuk tanah mencapai derajat konsolidasi $90 \%$ dibutuhkan waktu selama 14 minggu. Apabila dibandingkan dengan pola segiempat dengan jarak $1 \mathrm{~m}$ didapatkan bahwa tanah waktu untuk mencapai derajat konsolidasi $90 \%$ adalah 17 minggu.

4. Perkuatan tanah yang dipakai untuk mengatasi kelongsoran adalah geotekstil. Dengan program bantu didapatkan hasil pada timbunan $7 \mathrm{~m}$ dibutuhkan 17 lapis /m' geotekstil.

5. Vacuum Preloading memberikan hasil penurunan tambahan sebesar $0,691 \mathrm{~m}$ dan dapat disimpulkan bahwa keberadaan vacuum ini selain dapat mengurangi tinggi timbunan yang dibutuhkan, juga mempercepat terjadinya proses konsolidasi dengan memperbesar hasil pemampaan yang terjadi.

\section{Saran}

Perkuatan pada perencanaan ini menggunakan geotextile, agar perencanaan bias lebih efisien dan lebih efektif dapat menggunakan micropile sebagai variasi lain. Untuk mencapai hasil yang lebih ekonomis dan efektif juga dapat dilakukan variatif kedalaman pemasangan PVD seperti 1/2 atau 2/3 dari kedalaman tanah lunak. Juga pada program bantu dapat dilakukan verifikasi pemograman dan metode lainnya supaya didapatkan hasil yang lebih baik.

\section{DAFTAR PUSTAKA}

Das, Braja M. Mekanika Tanah (Prinsip-Prinsip Rekayasa Geoteknis). Jakarta: Erlangga, 1998.

Das, Braja M. Mekanika Tanah. Jakarta: Penerbit Erlangga, 1985.

Dokuchaev. Mekanika Tanah. Jakarta: Penerbit Erlangga, 1870.

Mochtar, Indrasurya B. Teknologi Perbaikan Tanah dan Alternatif Perencanaan pada Tanah Bermasalah. Surabaya: Jurusan Teknik Sipil FTSP-ITS, 2000.

Terzaghi, Karl and Ralph Brazelton Peck. Soil Mechanics in Engineering Practise. Jakarta: Erlangga, 1967.

Verhoef. Geologi Untuk Teknik SIpil. Jakarta: Erlangga, 1994. 
Analisis Alternatif Perbaikan Tanah Lunak dan Sangat

Christian Eka Putra, et al. Lunak pada Jalan Tol 